\title{
Foot ulcer revealing recurrence of Kaposi's sarcoma
}

\section{Mohammed Chaouche, Safae Zinoune, Abdellah Dah Cherif, Younes Barbach, Sara Elloudi, Hanane Baybay, Fatima Zahra Mernissi}

Department of Dermatology and Venereology, University Hospital Hassan II, Fez, Morocco

Corresponding author: Dr. Mohammed Chaouche, E-mail: medch11@hotmail.com

Kaposi's sarcoma (KS) is a human herpes virus-8 (HHV-8)-associated angioproliferative disorder, and its occurrence may be favored by human immunodeficiency virus (HIV) infection and iatrogenic immunosuppression $[1,2]$.

Four primary epidemiologic subtypes are commonly described: classic, AIDS-related, African, and iatrogenic [3].

Solitary ulcer KS has rarely been reported. A case of a 65-year-old woman, followed in our department for

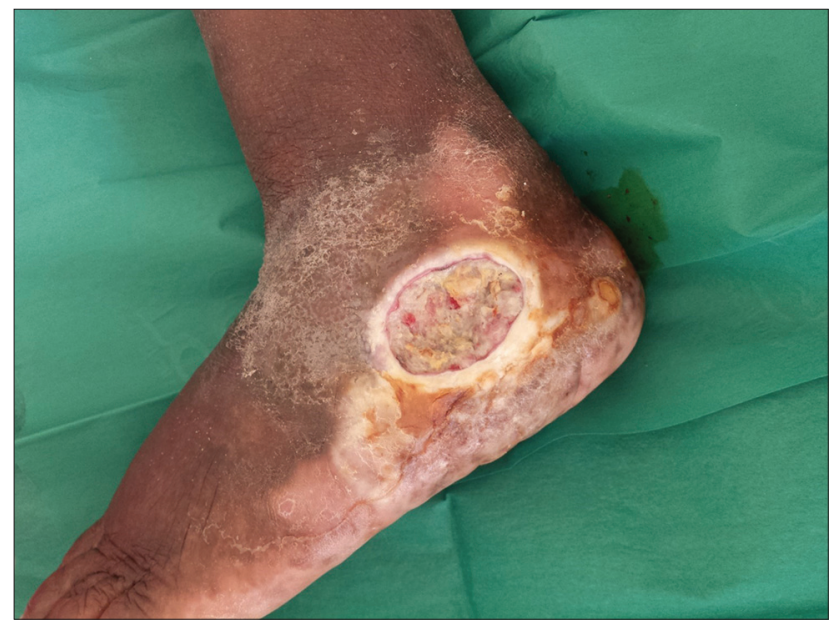

Figure 1: Foot ulcer revealing recurrence of Kaposi's sarcoma classical Kaposi sarcoma in remission for five years after treatment with bleomycin, who had presented for a year a foot ulceration oozing (Fig. 1) and resistant to antibiotic treatment and various wound healing dressings, a biopsy a been realized returning in favor of Kaposi's sarcoma.

\section{Consent}

The examination of the patient was conducted according to the Declaration of Helsinki principles.

\section{REFERENCES}

1. Wu XJ, Pu XM, Kang XJ, Halifu Y, An CX, Zhang DZ, et al. One hundred and five Kaposi sarcoma patients: A clinical study in Xinjiang, Northwest of China. J Eur Acad Dermatol Venereol. 2014;28:1545-52.

2. Schneider JW, Dittmer DP. Diagnosis and Treatment of Kaposi Sarcoma. Am J Clin Dermatol. 2017;18:529-39.

3. Dittmer DP, Damania B. Kaposi sarcoma-associated herpesvirus: immunobiology, oncogenesis, and therapy. J Clin Invest. 2016;126:3165-75.

Copyright by Mohammed Chaouche, et al. This is an open-access article distributed under the terms of the Creative Commons Attribution License, which permits unrestricted use, distribution, and reproduction in any medium, provided the original author and source are credited.

Source of Support: Nil, Conflict of Interest: None declared.

How to cite this article: Chaouche M, Zinoune S, Cherif AD, Barbach Y, Elloudi S, Baybay H, Mernissi FZ. Foot ulcer revealing recurrence of Kaposi's sarcoma. Our Dermatol Online. 2019;10(e):e12.1.

Submission: 16.01.2019; Acceptance: 20.04.2019

DOI:10.7241/ourd.2019e.12 